\title{
Perampanel, a potent AMPA receptor antagonist, protects against tetramethylenedisulfotetramine-induced seizures and lethality in mice: comparison with diazepam
}

\author{
Dorota Zolkowska $^{1}$ (D) . Ashish Dhir ${ }^{1}$ (D) Michael A. Rogawski ${ }^{1,2}$ (D)
}

Received: 8 February 2021 / Accepted: 15 April 2021 / Published online: 29 April 2021

(c) The Author(s) 2021

\begin{abstract}
Tetramethylenedisulfotetramine (TETS), a noncompetitive $\mathrm{GABA}_{\mathrm{A}}$ receptor antagonist, is a potent, highly lethal convulsant that is considered to be a chemical threat agent. Here, we assessed the ability of the AMPA receptor antagonist perampanel to protect against TETS-induced seizures and lethality in mice when administered before or after treatment with the toxicant. For comparison, we conducted parallel testing with diazepam, which is a first-line treatment for chemically induced seizures in humans. Pre-treatment of mice with either perampanel ( $1-4 \mathrm{mg} / \mathrm{kg}$, i.p.) or diazepam $(1-5 \mathrm{mg} / \mathrm{kg}$, i.p.) conferred protection in a dose-dependent fashion against tonic seizures and lethality following a dose of TETS $(0.2 \mathrm{mg} / \mathrm{kg}$, i.p.) that rapidly induces seizures and death. The $\mathrm{ED}_{50}$ values for protection against mortality were $1.6 \mathrm{mg} / \mathrm{kg}$ for perampanel and $2.1 \mathrm{mg} /$ $\mathrm{kg}$ for diazepam. Clonic seizures were unaffected by perampanel and only prevented in a minority of animals by high-dose diazepam. Neither treatment prevented myoclonic body twitches. Perampanel and diazepam also conferred protection against tonic seizures and lethality when administered $15 \mathrm{~min}$ following a $0.14 \mathrm{mg} / \mathrm{kg}$, i.p., dose of TETS and $5 \mathrm{~min}$ following a $0.2 \mathrm{mg} / \mathrm{kg}$, i.p., dose of TETS. Both posttreatments were highly potent at reducing tonic seizures and lethality in animals exposed to the lower dose of TETS whereas greater doses of both treatments were required in animals exposed to the larger dose of TETS. Neither treatment was as effective suppressing clonic seizures. In an experiment where $0.4 \mathrm{mg} / \mathrm{kg}$ TETS was administered by oral gavage and the treatment drugs were administered 5 min later, perampanel only partially protected against lethality whereas diazepam produced nearly complete protection. We conclude that perampanel and diazepam protect against TETS-induced tonic seizures and lethality but have less impact on clonic seizures. Both drugs could have utility in the treatment of TETS intoxication but neither eliminates all seizure activity.
\end{abstract}

Keywords Tetramethylenedisulfotetramine $\cdot$ Perampanel $\cdot$ Diazepam $\cdot$ Seizure $\cdot$ AMPA receptor antagonist

\section{Introduction}

Tetramethylenedisulfotetramine (TETS) is a potent convulsant poison (Zolkowska et al. 2012; Rice et al. 2017; Lauková et al. 2020) considered to be a chemical threat agent by the National Institutes of Health (Jett and Spriggs 2020) and other health authorities (Patocka et al. 2018). TETS is

Michael A. Rogawski

rogawski@ucdavis.edu

1 Department of Neurology, School of Medicine, University of California, Davis, Sacramento, CA 95817, USA

2 Department of Pharmacology, School of Medicine, University of California, Davis, Sacramento, CA 95817, USA believed to induce lethal seizures by blocking brain $\mathrm{GABA}_{\mathrm{A}}$ receptors (Bowery et al. 1975; Large 1975; Dray 1975; Roberts et al. 1981; Nik et al. 2017; Pressly et al. 2021). No specific antidote for TETS intoxication is known. However, recent studies indicate that positive modulators of $\mathrm{GABA}_{\mathrm{A}}$ receptors, such as diazepam, can prolong the time to onset of TETS-induced convulsions and reduce lethality (Shakarjian et al. 2012; Vito et al. 2014; Bruun et al. 2015; Moffett et al. 2019).

Inhibitors of NMDA and AMPA ionotropic glutamate receptors, which are the principal mediators of fast excitatory neurotransmission in the brain, have been extensively studied as potential seizure treatments (Löscher and Rogawski 2002). While NMDA receptor antagonists are anticonvulsant in certain in vitro and in vivo models, they can paradoxically promote seizures in other situations 
(Rogawski 2013). Therefore, it is of interest that NMDA antagonists, such as ketamine and dizocilpine (MK-801), may increase the frequency of TETS-induced seizures (Shakarjian et al. 2012) although when used in combination with positive modulators of $\mathrm{GABA}_{\mathrm{A}}$ receptors, these deleterious actions are not observed (Shakarjian et al. 2015). Unlike NMDA receptor antagonists, which have not proven useful in the clinical treatment of seizures in people with epilepsy, AMPA receptors are a validated clinical target for epilepsy treatment. Perampanel [2-(2-oxo-1-phenyl-5-pyridin-2-yl1,2-dihydropyridin-3-yl)benzonitrile; E2007], a potent noncompetitive AMPA receptor antagonist, has been shown to reduce the frequency of focal-onset seizures and primary generalized tonic seizures in people with epilepsy (Steinhoff 2014). In in vitro studies, perampanel selectively inhibits AMPA receptor-induced synaptic excitation without affecting responses mediated by NMDA or kainate receptors (Ceolin et al. 2012; Rogawski and Hanada 2013; Chen et al. 2014). Moreover, perampanel is believed to be highly selective for AMPA receptors and is not known to interact with other anti-seizure brain targets.

As is the case for other AMPA receptor antagonists, perampanel exhibits broad-spectrum anti-seizure activity in animal models. It potently protects mice against seizures induced by the $\mathrm{GABA}_{\mathrm{A}}$ receptor antagonist pentylenetetra$\mathrm{zol}\left(\mathrm{ED}_{50}, 0.94 \mathrm{mg}\right.$, p.o.); it is effective against audiogenic seizures in DBA/2 mice; and it has activity in the maximal electroshock (MES) and $6 \mathrm{~Hz}$ tests, as well as in kindled seizures (Hanada et al. 2011). Perampanel also reduces the frequency of focal electrographic seizures in mice that exhibit spontaneous recurrent seizures following intrahippocampal injection of kainic acid (Twele et al. 2015). Finally, perampanel suppresses behavioral and electrographic seizures in the rat lithium-pilocarpine (Hanada et al. 2014) and diisopropylfluorophosphate (Dhir et al. 2020) models of status epilepticus.

Given the broad-spectrum activity of peramapanel in animal seizure models, we hypothesized that it would also be effective in treating TETS-induced seizures. In the present study, we assessed perampanel in comparison with diazepam. We first confirmed the activity of perampanel in the MES test to verify its anti-seizure efficacy and potency when administered by the parenteral route in the strain of mice used in our laboratory. With dosing and time course of action information in hand, we then demonstrated that pretreatment with both perampanel and diazepam reduced the incidence and severity of TETS-induced tonic seizures and lethality although they did not eliminate myoclonic seizures. However, pre-treatment is not feasible in accidental or intentional poisoning. Therefore, we sought to assess the activity of the two anti-seizure drugs with post-treatment. Both were found to protect against tonic seizures and lethality when administered following TETS exposure, but in a group of animals that received a high oral dose of TETS, perampanel failed to perform as well as diazepam.

\section{Materials and methods}

\section{Animals}

Male NIH Swiss mice (22-30 g) were housed four per cage. Animals were kept in a vivarium under controlled laboratory conditions (temperature $22-26{ }^{\circ} \mathrm{C}$; humidity $40-50 \%$ ) with an artificial 12-h light/dark cycle and free access to food and water. Animals were allowed to acclimate to the vivarium for $\geq 5$ days. The experiments were performed during the light phase of the light/dark cycle after $a \geq 30$-min period of acclimation to the experimental room. Animals were maintained in facilities fully accredited by the Association for Assessment and Accreditation of Laboratory Animal Care, and all studies were performed under protocols approved by the University of California, Davis, Institutional Animal Care and Use Committee in strict compliance with the Guide for the Care and Use of Laboratory Animals of the National Research Council (National Academy Press, Washington, DC; http://www.nap.edu/readingroom/books/labrats/). Mice that survived testing were euthanized with $\mathrm{CO}_{2}$.

\section{Test substances and formulations}

TETS was synthesized by a modification of the procedure of Esser et al. (1991). Solutions of TETS were made in 100\% DMSO at a concentration of $1 \mathrm{mg} / \mathrm{ml}$. Further dilutions were made in $10 \%$ DMSO in $0.9 \%$ saline. TETS was injected intraperitoneally at a dose of either $0.14 \mathrm{mg} / \mathrm{kg}$ or $0.2 \mathrm{mg} /$ $\mathrm{kg}$, or administered by oral gavage at a dose of $0.4 \mathrm{mg} / \mathrm{kg}$. Perampanel was supplied by Eisai Inc. (Ibaraki Prefecture, Japan) and diazepam was purchased from Sigma-Aldrich (St Louis, MO). Perampanel and diazepam were prepared as suspensions in $1 \%$ Tween 80 in sterile saline and were administered intraperitoneally. Drug solutions for intraperitoneal or oral dosing were administered in a volume equaling $10-\mathrm{ml} / \mathrm{kg}$ body weight.

\section{MES seizure test}

Animals were subjected to a $0.2-\mathrm{s}, 60-\mathrm{Hz}$ electrical stimulus through corneal electrodes. The electroshock unit was adjusted to deliver a constant current of $50 \mathrm{~mA}$. Animals failing to show tonic hindlimb extension were scored as protected (Kokate et al. 1994). To obtain dose-response data, vehicle or perampanel was administered i.p. 10 min before the electrical stimulus. The pre-treatment interval was based on the time of maximal effect in the time course experiment of Fig. 1A. 

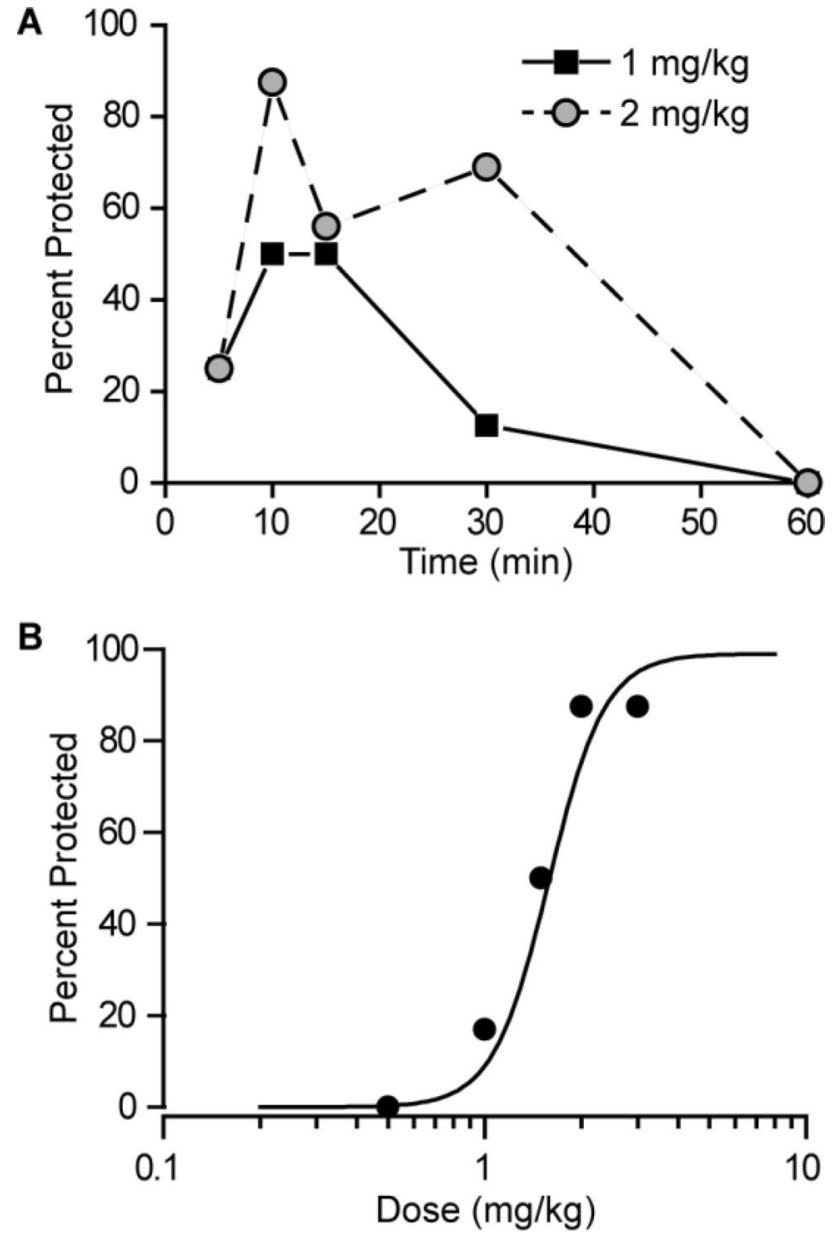

Fig. 1 A Time course for protection by perampanel at the doses of 1 and $2 \mathrm{mg} / \mathrm{kg}$, i.p., in the maximal electroshock (MES) test. The interval between perampanel injection and the electrical stimulus is plotted on the abscissa and the percentage of animals protected against seizures is plotted on the ordinate. Each point represents at least eight mice. B Dose-response relationship for protection by perampanel in the MES test. Perampanel was administered $10 \mathrm{~min}$ before the electrical stimulus. Each point represents 8-24 mice

\section{Motor impairment test}

Perampanel was evaluated for motor toxicity using a modification of the horizontal screen test as described previously (Kokate et al. 1994). Mice were placed on a horizontally oriented grid (consisting of parallel 1.5-mm-diameter rods situated $1 \mathrm{~cm}$ apart) and the grid was inverted. Animals that fell from the grid within $10 \mathrm{~s}$ were scored as impaired.

\section{Scoring of TETS-induced seizures}

Animals were observed for $1 \mathrm{~h}$ after administration of TETS. During this period, the occurrence of myoclonic body twitches, clonic seizures (rhythmic movements of forelimbs- and/or hindlimbs for $\geq 5 \mathrm{~s}$ with or without loss of balance and falling), wild running, tonic seizures (loss of posture, forelimb tonic extension with hindlimb tonic contraction and/or extension that in some cases was followed by clonic movements of all limbs) and death was recorded. In experiments in which a treatment drug was administered after dosing with TETS, clonic seizures often occurred prior to administration of the treatment but was excluded in the scoring. In the assessment of the time to occurrence of clonic seizures (Fig. 4), a clonic seizure was considered terminated when all clonic seizure signs ceased completely for at least $1 \mathrm{~min}$. The severity of tonic seizures was scored as either not present (0), mild (1), moderate (2), or severe (3), where "mild" indicates brief and transitory episodes of tonic forelimb extension; "moderate" indicates tonic forelimb extension with tonic hindlimb contraction that may be followed by continuous episodes of clonic seizures with loss of posture; and "severe" indicates tonic forelimb extension followed by tonic hindlimb extension. Mean convulsion severity was calculated as the sum of the individual scores divided by the number of animals. In most cases, the animals were euthanized after the $1 \mathrm{~h}$ observation period. In some cases, surviving animals were returned to the vivarium and their clinical status assessed at $24 \mathrm{~h}$. All scoring was by the same experienced unblinded observer aided by another observer who provided verification.

\section{Data analysis}

To construct dose-response curves, perampanel and diazepam were tested at several doses spanning the dose $\left(\mathrm{ED}_{50}\right)$ corresponding to protection against seizures or mortality or induction of motor impairment in $50 \%$ of animals. $\mathrm{ED}_{50}$ values and their corresponding standard error (SEM) and 95\% confidence limits $(95 \% \mathrm{CI}$ ) were determined using a probit regression model implemented as a custom-designed application in RStudio. In the analysis to determine $\mathrm{ED}_{50}$ values for TETS-induced tonic seizures and lethality, the slopes of the perampanel and diazepam dose-response models were constrained to be the same. Curves to dose-response data in Figs. 1, 2 were fit by eye with the Hill equation.

\section{Results}

\section{MES seizure test}

In confirmation of a previous report by Hanada et al. (2011), we found that pre-treatment with perampanel conferred protection in the MES seizure test. As shown in Fig. 1A, perampanel at a dose of $1 \mathrm{mg} / \mathrm{kg}$, i.p., provided maximal protection of $50 \%$ of the animals at the 10 and $15 \mathrm{~min}$ time points. A smaller number of animals were protected at $30 \mathrm{~min}$ and protection was not present at $60 \mathrm{~min}$. A higher 

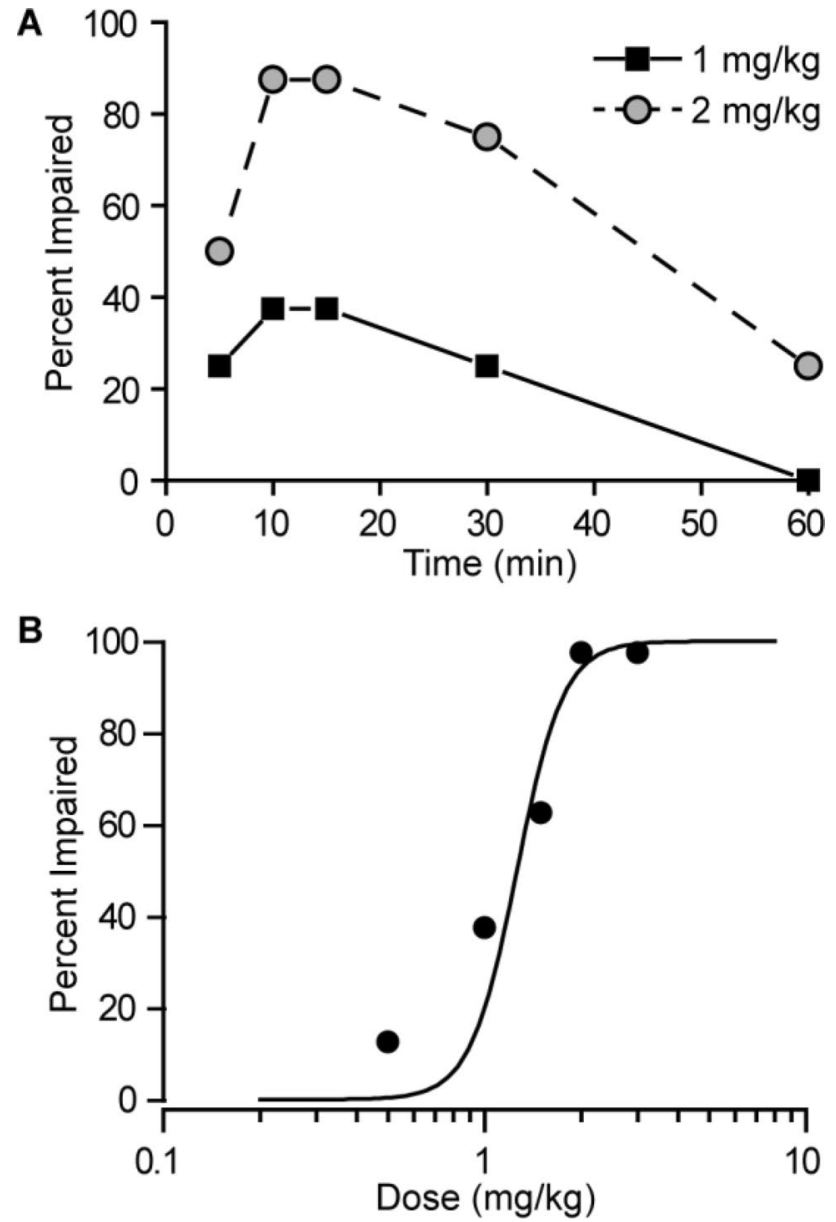

Fig. 2 A Time course for induction of motor impairment by perampanel at the doses of 1 and $2 \mathrm{mg} / \mathrm{kg}$, i.p., in the horizontal screen test. The interval between perampanel injection and testing is plotted on the abscissa and the percentage of animals exhibiting impairment is plotted on the ordinate. Each point represents at least eight mice. B Dose-response relationship for induction of motor impairment by perampanel. Perampanel was administered $10 \mathrm{~min}$ before the electrical stimulus. Each point represents 8-24 mice

dose of perampanel $(2 \mathrm{mg} / \mathrm{kg})$ conferred nearly complete seizure protection $(85.6 \%)$ at $10 \mathrm{~min}$, and substantial protection up to $30 \mathrm{~min}$, as was the case with the lower dose, protection was no longer present at $60 \mathrm{~min}$. We conducted a dose-response study with a 10 min pre-treatment interval. The results shown in Fig. 1B indicated that the protection occurred in a dose-dependent fashion with $\mathrm{ED}_{50}$ value of $1.50 \mathrm{mg} / \mathrm{kg}$ (95\% CI 1.22-1.77).

\section{Motor impairment test}

As shown in Fig. 2A, perampanel at doses of 1 and $2 \mathrm{mg} / \mathrm{kg}$, i.p., caused motor impairment that followed a similar time course as MES seizure protection. The dose-response study shown in Fig. $2 \mathrm{~B}$ indicated that the $\mathrm{ED}_{50}$ value is $1.19 \mathrm{mg} /$ $\mathrm{kg}$ (95\% CI 0.89-1.48). Animals exhibiting motor impairment did not exhibit loss of righting reflex at any of the doses tested.

\section{Effect of pre-treatment with peramapanel or diazepam on seizures and lethality induced by $0.2 \mathrm{mg} / \mathrm{kg}$ TETS}

Animals pre-treated with vehicle who subsequently received a $0.2 \mathrm{mg} / \mathrm{kg}$, i.p., dose of TETS exhibited myoclonic twitches and clonic seizures, and tonic seizures of maximum severity (Table 1 and Fig. 3). These animals all expired during the $1 \mathrm{~h}$ observation period. Pre-treatment with perampanel $(1-4 \mathrm{mg} / \mathrm{kg}$, i.p.) $10 \mathrm{~min}$ before TETS or diazepam $(1-5 \mathrm{mg} /$ $\mathrm{kg}$, i.p.) $30 \mathrm{~min}$ before TETS did not reduce the occurrence of myclonic body twitches or clonic seizures, except that the highest doses of diazepam did eliminate clonic seizures in some animals. These doses of perampanel and diazepam did cause a dose-dependent reduction in the incidence and severity of tonic seizures and improved survival in a dosedependent fashion so that all animals survived when pretreated with $4 \mathrm{mg} / \mathrm{kg}$ or higher doses of each drug. The $\mathrm{ED}_{50}$ values for perampanel and diazepam protection against tonic seizures and lethality are presented in Table 5.

\section{Effect of post-treatment with perampanel or diazepam on seizures and lethality induced by $0.14 \mathrm{mg} / \mathrm{kg}$ or $0.2 \mathrm{mg} / \mathrm{kg}$ TETS}

In cases of accidental or intentional exposure, treatments would be administered following exposure to TETS and we therefore sought to determine if perampanel is effective when administered in a post-exposure paradigm. With a $0.14 \mathrm{mg} / \mathrm{kg}$, i.p., dose of TETS animals exhibited a delayed onset to seizure signs and survived sufficiently long to permit treatment administration 15 min after TETS exposure. As shown in Table 2 and Fig. 3, perampanel $(0.1-2 \mathrm{mg} / \mathrm{kg}$, i.p.) only minimally affected clonic seizures but did cause dose-dependent protection against tonic seizure and lethality. Diazepam $(0.0625-1 \mathrm{mg} / \mathrm{kg}$, i.p.) provided a similar dosedependent protection. The $\mathrm{ED}_{50}$ values for perampanel and diazepam protection against tonic seizures and lethality are presented in Table 5.

Following administration of the higher $(0.2 \mathrm{mg} / \mathrm{kg})$ dose of TETS used in the pre-treatment experiments (see above), animals experienced the rapid occurrence of myoclonic twitches, clonic seizures, tonic seizures and death within less than $15 \mathrm{~min}$, so that a briefer post-treatment interval is required. We therefore conducted experiments with a posttreatment interval of $5 \mathrm{~min}$. As shown in Table 3, doses of perampanel from $0.5 \mathrm{mg} / \mathrm{kg}$ to $6 \mathrm{mg} / \mathrm{kg}$ had minimal effect on clonic seizures as in the other pre-treatment and posttreatment experiments. These higher doses of perampanel 
Table 1 Effects of pre-treatment with i.p. perampanel $10 \mathrm{~min}$ before and i.p. diazepam $30 \mathrm{~min}$ before TETS $(0.2 \mathrm{mg} / \mathrm{kg}$, i.p.) on the incidence of seizure signs, tonic seizure severity, and the incidence of lethality during a $1 \mathrm{~h}$ observation period

\begin{tabular}{|c|c|c|c|c|c|c|}
\hline Treatment (dose) & $N$ & $\begin{array}{l}\text { Myoclonic } \\
\text { body } \\
\text { twitches }\end{array}$ & Clonic seizures & Tonic seizures & $\begin{array}{l}\text { Mean tonic } \\
\text { seizure } \\
\text { severity }\end{array}$ & Dead $1 \mathrm{~h}$ \\
\hline $\begin{array}{l}\text { Vehicle for perampanel } \\
\text { group (10 min pre- } \\
\text { treatment) }\end{array}$ & 8 & $100 \%$ & $100 \%$ & $100 \%$ & 3.0 & $100 \%$ \\
\hline Perampanel $(1 \mathrm{mg} / \mathrm{kg})$ & 8 & $100 \%$ & $100 \%$ & $100 \%$ & 2.4 & $75 \%$ \\
\hline Perampanel $(1.5 \mathrm{mg} / \mathrm{kg})$ & 8 & $100 \%$ & $100 \%$ & $87.5 \%$ & 2.3 & $50 \%$ \\
\hline Perampanel $(2.3 \mathrm{mg} / \mathrm{kg})$ & 8 & $100 \%$ & $100 \%$ & $37.5 \%$ & 1.0 & $25 \%$ \\
\hline Perampanel (3 mg/kg) & 8 & $100 \%$ & $100 \%$ & $25 \%$ & 0.8 & $25 \%$ \\
\hline Perampanel (4 mg/kg) & 8 & $100 \%$ & $100 \%$ & $0 \%$ & 0 & $0 \%$ \\
\hline $\begin{array}{l}\text { Vehicle for diazepam } \\
\text { group ( } 30 \text { min pre- } \\
\text { treatment) }\end{array}$ & 8 & $100 \%$ & $100 \%$ & $100 \%$ & 3.0 & $100 \%$ \\
\hline Diazepam (1 mg/kg) & 8 & $100 \%$ & $100 \%$ & $100 \%$ & 3.0 & $100 \%$ \\
\hline Diazepam $(1.5 \mathrm{mg} / \mathrm{kg})$ & 8 & $100 \%$ & $100 \%$ & $87.5 \%$ & 2.6 & $87.5 \%$ \\
\hline Diazepam (2 mg/kg) & 8 & $100 \%$ & $100 \%$ & $50 \%$ & 1.5 & $50 \%$ \\
\hline Diazepam (3 mg/kg) & 8 & $100 \%$ & $100 \%$ & $25 \%$ & 0.8 & $25 \%$ \\
\hline Diazepam (4 mg/kg) & 8 & $100 \%$ & $87.5 \%$ & $0 \%$ & 0 & $0 \%$ \\
\hline Diazepam (5 mg/kg) & 8 & $100 \%$ & $62.5 \%$ & $0 \%$ & 0 & $0 \%$ \\
\hline
\end{tabular}

${ }^{1}$ Tonic seizures were scored on a 4-point scale $(0-3)$ where 3 is maximum severity; the values shown are the means

\section{O TETS $(0.14 \mathrm{mg} / \mathrm{kg})$, posttreatment \\ O TETS $(0.2 \mathrm{mg} / \mathrm{kg})$, pretreatment \\ - TETS $(0.2 \mathrm{mg} / \mathrm{kg})$, posttreatment}

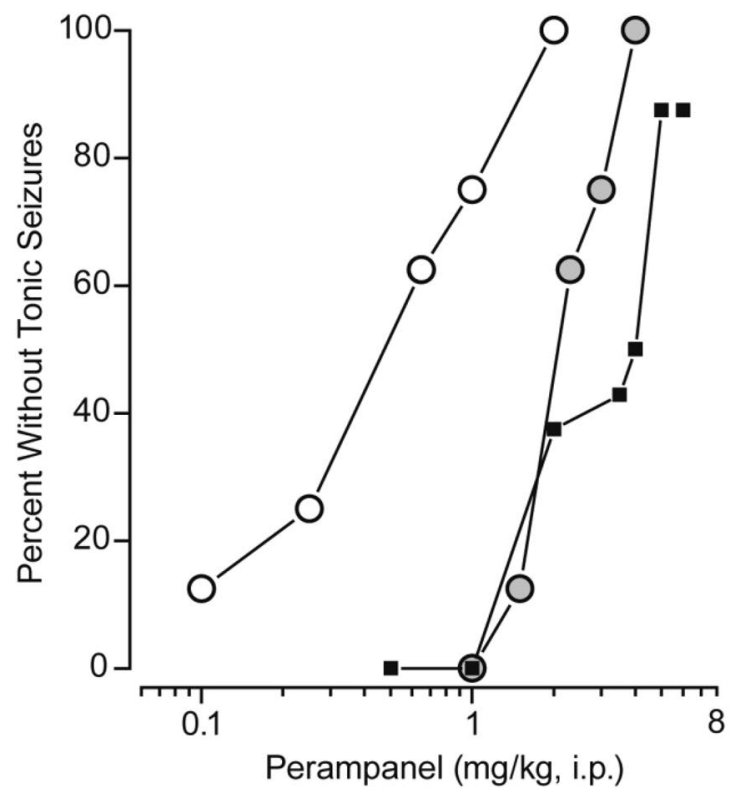

Fig. 3 Dose-response relationships for perampanel and diazepam protection against tonic seizures in the experiment with pre-treatment prior to a $0.2 \mathrm{mg} / \mathrm{kg}$, i.p., dose of TETS and in the experiments with

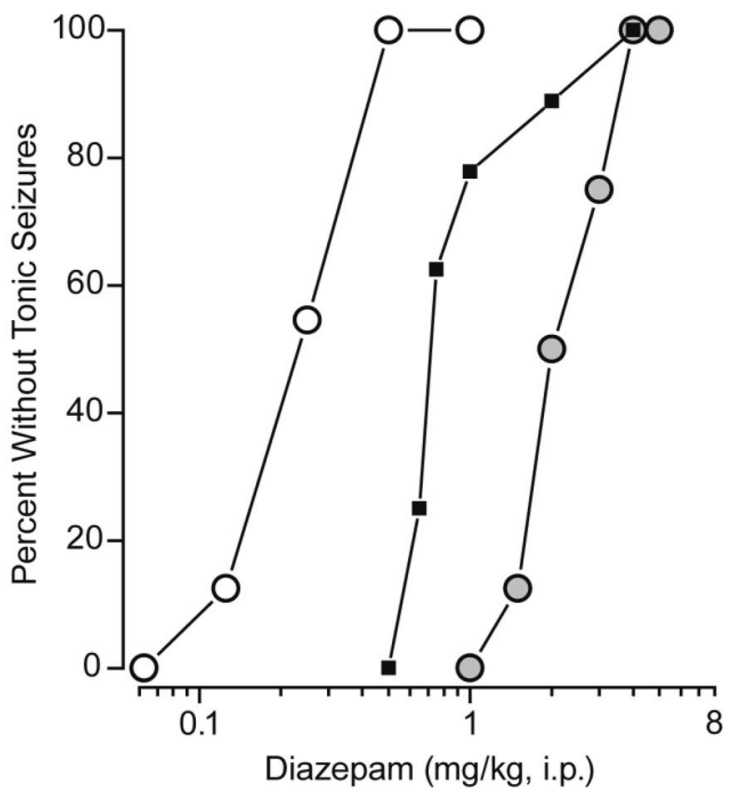

post-treatment following a $0.14 \mathrm{mg} / \mathrm{kg}$, i.p., or $0.2 \mathrm{mg} / \mathrm{kg}$, i.p., dose of TETS. $\mathrm{ED}_{50} \pm$ SEM and $95 \%$ CI values are presented in Table 5 
Table 2 Effects of posttreatment with perampanel and diazepam i.p. $15 \mathrm{~min}$ following a $0.14 \mathrm{mg} / \mathrm{kg}$, i.p., dose of TETS on the incidence of clonic and tonic seizures, tonic seizure severity, and the incidence of lethality at $1 \mathrm{~h}$ and $24 \mathrm{~h}$
Table 3 Effects of posttreatment with perampanel and diazepam i.p. 5 min after TETS $(0.2 \mathrm{mg} / \mathrm{kg}$, i.p.) on the incidence of clonic and tonic seizures, tonic seizure severity, and the incidence of lethality during a $1 \mathrm{~h}$ observation period

\begin{tabular}{lrlllll}
\hline Treatment (dose) & $N \begin{array}{l}\text { Clonic seizures } \\
\text { after treatment }\end{array}$ & Tonic seizures & $\begin{array}{l}\text { Mean tonic } \\
\text { seizure sever- } \\
\text { ity }\end{array}$ & $\begin{array}{l}\text { Dead } 1 \mathrm{~h} \\
\text { Dead or unsal- } \\
\text { vageable 24 h }\end{array}$ \\
\hline Vehicle & 32 & $100 \%$ & $90.6 \%$ & 2.7 & $90.6 \%$ & $96.9 \%$ \\
Perampanel $(0.1 \mathrm{mg} / \mathrm{kg})$ & 8 & $100 \%$ & $87.5 \%$ & 2.6 & $87.5 \%$ & $100 \%$ \\
Perampanel $(0.25 \mathrm{mg} / \mathrm{kg})$ & 8 & $100 \%$ & $75 \%$ & 2.3 & $37.5 \%$ & $50 \%$ \\
Perampanel $(0.65 \mathrm{mg} / \mathrm{kg})$ & 8 & $100 \%$ & $37.5 \%$ & 1.1 & $12.5 \%$ & $12.5 \%$ \\
Perampanel $(1 \mathrm{mg} / \mathrm{kg})$ & 8 & $87.5 \%$ & $25 \%$ & 0.8 & $25 \%$ & $25 \%$ \\
Perampanel $(2 \mathrm{mg} / \mathrm{kg})$ & 8 & $87.5 \%$ & $0 \%$ & 0 & $0 \%$ & $0 \%$ \\
Diazepam $(0.0625 \mathrm{mg} / \mathrm{kg})$ & 8 & $100 \%$ & $100 \%$ & 3.0 & $75 \%$ & $100 \%$ \\
Diazepam $(0.125 \mathrm{mg} / \mathrm{kg})$ & 8 & $100 \%$ & $87.5 \%$ & 2.6 & $87.5 \%$ & $87.5 \%$ \\
Diazepam $(0.25 \mathrm{mg} / \mathrm{kg})$ & 22 & $95.5 \%$ & $45.5 \%$ & 1.4 & $36.4 \%$ & $59.1 \%$ \\
Diazepam $(0.5 \mathrm{mg} / \mathrm{kg})$ & 17 & $100 \%$ & $0 \%$ & 0 & $0 \%$ & $29.4 \%$ \\
Diazepam $(1 \mathrm{mg} / \mathrm{kg})$ & 8 & $62.5 \%$ & $0 \%$ & 0 & $0 \%$ & $12.5 \%$ \\
\hline
\end{tabular}

\begin{tabular}{lrlllc}
\hline Treatment (dose) & $N$ & $\begin{array}{l}\text { Clonic seizures } \\
\text { after treatment }\end{array}$ & Tonic seizures & $\begin{array}{l}\text { Mean tonic sei- } \\
\text { zure severity }\end{array}$ & Dead 1 h \\
\hline Vehicle & 16 & $100 \%$ & $100 \%$ & 3 & $100 \%$ \\
Perampanel $(0.5 \mathrm{mg} / \mathrm{kg})$ & 7 & $100 \%$ & $100 \%$ & 3 & $85.7 \%$ \\
Perampanel $(1 \mathrm{mg} / \mathrm{kg})$ & 16 & $100 \%$ & $100 \%$ & 2.7 & $75 \%$ \\
Perampanel $(2 \mathrm{mg} / \mathrm{kg})$ & 16 & $100 \%$ & $62.5 \%$ & 1.9 & $62.5 \%$ \\
Perampanel $(3.5 \mathrm{mg} / \mathrm{kg})$ & 7 & $85.7 \%$ & $57.1 \%$ & 1.7 & $42.9 \%$ \\
Perampanel $(4 \mathrm{mg} / \mathrm{kg})$ & 16 & $100 \%$ & $50 \%$ & 1.4 & $31.3 \%$ \\
Perampanel $(5 \mathrm{mg} / \mathrm{kg})$ & 8 & $100 \%$ & $12.5 \%$ & 0.3 & $0 \%$ \\
Perampanel $(6 \mathrm{mg} / \mathrm{kg})$ & 8 & $87.5 \%$ & $12.5 \%$ & 0.4 & $12.5 \%$ \\
Diazepam $(0.5 \mathrm{mg} / \mathrm{kg})$ & 8 & $100 \%$ & $100 \%$ & 3 & $87.5 \%$ \\
Diazepam $(0.65 \mathrm{mg} / \mathrm{kg})$ & 14 & $100 \%$ & $78.6 \%$ & 2.4 & $78.6 \%$ \\
Diazepam $(0.75 \mathrm{mg} / \mathrm{kg})$ & 8 & $87.5 \%$ & $37.5 \%$ & 1.1 & $37.5 \%$ \\
Diazepam $(1 \mathrm{mg} / \mathrm{kg})$ & 9 & $88.9 \%$ & $22.2 \%$ & 0.7 & $11.1 \%$ \\
Diazepam $(2 \mathrm{mg} / \mathrm{kg})$ & 9 & $44 \%$ & $11.1 \%$ & 0.3 & $11.1 \%$ \\
Diazepam $(4 \mathrm{mg} / \mathrm{kg})$ & 8 & $0 \%$ & $0 \%$ & 0 & $0 \%$ \\
\hline
\end{tabular}

did confer dose-dependent protection from tonic seizures (Fig. 3) and death. Diazepam also provided protection against tonic seizures and lethality, and high doses inhibited clonic seizures. The $\mathrm{ED}_{50}$ values for perampanel and diazepam protection against tonic seizures and lethality are presented in Table 5.

\section{Effect of post-treatment with perampanel or diazepam on oral TETS poisoning}

Ingestion, either accidental or intentional, is the most common route of poisoning by TETS. We previously found that the $\mathrm{ED}_{50}$ for induction of tonic seizures and lethality for orally administered TETS in mice is $0.22 \mathrm{mg} / \mathrm{kg}$ (Zolkowska et al. 2012). In the present study, we sought to determine the efficacy of perampanel and diazepam administered following oral exposure to TETS and delivered a $0.4 \mathrm{mg} / \mathrm{kg}$ dose by oral gavage, which was sufficient to induce tonic seizures and lethality in nearly all animals in the absence of treatment. At this dose, clonic seizures began on average $\sim 5$ min after dosing and tonic seizures and lethality occurred at $\sim 20 \mathrm{~min}$. In some animals, tonic seizures occurred earlier than the $5 \mathrm{~min}$ treatment time; these animals were excluded from the analysis. Perampanel at doses of $2 \mathrm{mg} / \mathrm{kg}$ to $6 \mathrm{mg} / \mathrm{kg}$ reduced the incidence and severity of tonic seizures and conferred partial protection against lethality (Table 4). Increasing the dose of perampanel to $8 \mathrm{mg} / \mathrm{kg}$ and $10 \mathrm{mg} / \mathrm{kg}$ did not provide further protection; therefore, we did not calculate $\mathrm{ED}_{50}$ values. Diazepam at high doses $(2.5 \mathrm{mg} / \mathrm{kg}$ to $4 \mathrm{mg} / \mathrm{kg}$ ) was somewhat more effective but still did not confer complete protection. During the interval prior to treatment, some animals did not exhibit seizure signs whereas others exhibited myoclonic twitches and up to one clonic seizure. Figure 4 shows the time of occurrence 
Table 4 Effects of posttreatment with perampanel and diazepam i.p. 5 min after oral administration of TETS

$(0.4 \mathrm{mg} / \mathrm{kg})$ on the incidence of clonic and tonic seizures, tonic seizure severity, and the incidence of lethality at $1 \mathrm{~h}$ and $24 \mathrm{~h}$

\begin{tabular}{lrlllll}
\hline Treatment (dose) & $N$ & $\begin{array}{l}\text { Clonic Seizures } \\
\text { after treatment }\end{array}$ & Tonic seizures & $\begin{array}{l}\text { Mean tonic } \\
\text { seizure sever- } \\
\text { ity }\end{array}$ & $\begin{array}{l}\text { Dead } 1 \mathrm{~h} \\
\text { Dead or unsal- } \\
\text { vageable 24 h }\end{array}$ \\
\hline Vehicle & 15 & $100 \%$ & $100 \%$ & 3.0 & $100 \%$ & $100 \%$ \\
Perampanel (2 mg/kg) & 16 & $100 \%$ & $75 \%$ & 2.0 & $43.8 \%$ & $100 \%$ \\
Perampanel (4 mg/kg) & 16 & $87.5 \%$ & $56 \%$ & 1.6 & $44 \%$ & $75 \%$ \\
Perampanel (6 mg/kg) & 24 & $95.8 \%$ & $41.7 \%$ & 1.1 & $33.3 \%$ & $58.3 \%$ \\
Perampanel (8 mg/kg) & 15 & $80 \%$ & $53 \%$ & 1.5 & $47 \%$ & $47 \%$ \\
Perampanel (10 mg/kg) & 7 & $85.7 \%$ & $57.1 \%$ & 1.6 & $42.9 \%$ & $85.7 \%$ \\
Diazepam (1 mg/kg) & 7 & $85.7 \%$ & $71 \%$ & 2.1 & $71.4 \%$ & $71.4 \%$ \\
Diazepam (2 mg/kg) & 15 & $93.3 \%$ & $80 \%$ & 2.4 & $66.7 \%$ & $66.7 \%$ \\
Diazepam (2.5 mg/kg) & 8 & $75 \%$ & $12.5 \%$ & 0.38 & $12.5 \%$ & $12.5 \%$ \\
Diazepam (3 mg/kg) & 8 & $75 \%$ & $12.5 \%$ & 0.38 & $0 \%$ & $12.5 \%$ \\
Diazepam (4 mg/kg) & 7 & $14.3 \%$ & $14.3 \%$ & 0.43 & $14.3 \%$ & $14.3 \%$ \\
\hline
\end{tabular}

Diazepam

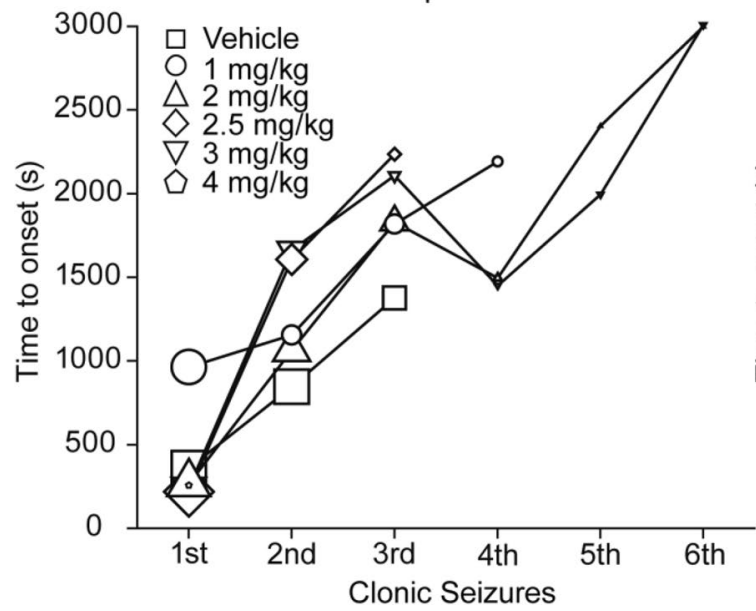

Fig. 4 Time to occurrence of clonic seizures in mice treated with vehicle or various doses of either diazepam or perampanel administered $5 \mathrm{~min}$ after a $0.4 \mathrm{mg} / \mathrm{kg}$, p.o., dose of TETS. Increasing doses of the treatments generally reduce the incidence and severity of tonic seizures, and improve survival. However, the occurrence of clonic seizures is more resistant. Data points indicate mean time to onset (in

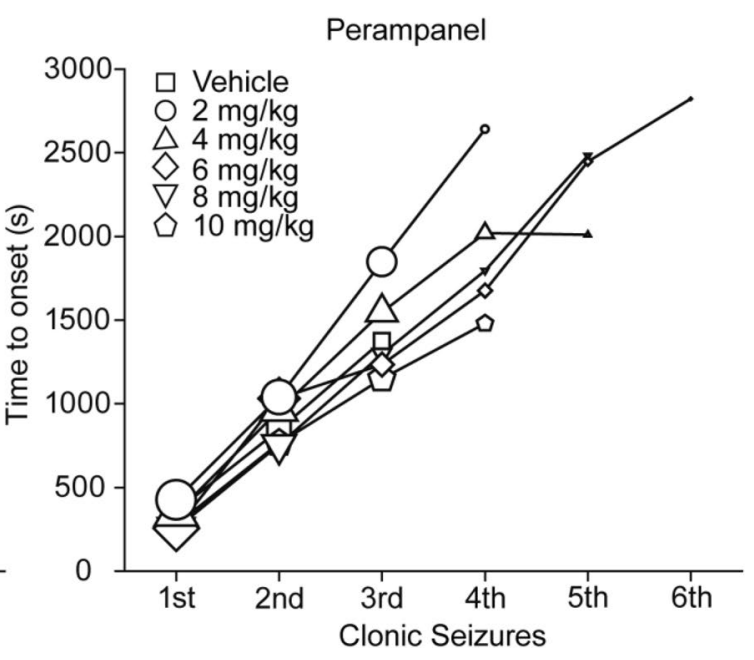

seconds) of the $n$th clonic seizure during the $3600 \mathrm{~s}$ period following administration of the treatment, which was $5 \mathrm{~min}$ after oral gavage of TETS. The size of the symbols represents the fraction of animals experiencing the $n$th clonic seizure in relation to the total number in the dose group

treatment for focal-onset seizures and primary generalized tonic-clonic seizures (Rogawski 2017). The purpose of the present study was to characterize the anti-seizure efficacy of perampanel in models of acute TETS-induced poisoning in mice. For comparison, we conducted a parallel series of experiments with diazepam, a $\mathrm{GABA}_{\mathrm{A}}$ receptor positive allosteric modulator that is considered a first-line standardof-care treatment for acute seizures (Greenfield et al. 2021). We used a low $(0.14 \mathrm{mg} / \mathrm{kg})$ and a higher $(0.2 \mathrm{mg} / \mathrm{kg})$ dose of TETS administered parenterally and a single high dose $(0.4 \mathrm{mg} / \mathrm{kg})$ administered by oral gavage. The treatments were administered prior to TETS (pre-treatment) and also at intervals following TETS (post-treatment). 
Table 5 Summary of $\mathrm{ED}_{50}$ values for activity in MES test, motor impairment test, and for protection against TETS-induced tonic seizures and lethality

\begin{tabular}{|c|c|c|c|}
\hline \multirow[t]{2}{*}{ Test } & \multicolumn{3}{|c|}{$\mathrm{ED}_{50} \pm \mathrm{SEM}, \mathrm{mg} / \mathrm{kg}[95 \% \mathrm{CI}]$} \\
\hline & & Perampanel & Diazepam \\
\hline MES & & $1.50 \pm 0.14[1.22-1.78]$ & \\
\hline Horizontal Screen & & $1.19 \pm 0.15[0.89-1.48]$ & \\
\hline \multirow[t]{2}{*}{ TETS $(0.2 \mathrm{mg} / \mathrm{kg}$, i.p. $)$, pre-treatment } & Tonic seizures & $2.19 \pm 0.19[1.81-2.56]$ & $2.15 \pm 0.19[1.79-2.51]$ \\
\hline & Lethality at $1 \mathrm{~h}$ & $1.63 \pm 0.18[1.27-1.98]$ & $2.12 \pm 0.23[1.68-2.57]$ \\
\hline \multirow[t]{2}{*}{ TETS $(0.14 \mathrm{mg} / \mathrm{kg}$, i.p. $)$, post-treatment $(15 \mathrm{~min})$} & Tonic seizures & $0.44 \pm 0.08[0.28-0.60]$ & $0.21 \pm 0.03[0.15-0.27]$ \\
\hline & Lethality at $24 \mathrm{~h}$ & $0.34 \pm 0.08[0.19-0.49]$ & $0.32 \pm 0.05[0.23-0.42]$ \\
\hline \multirow[t]{2}{*}{ TETS $(0.2 \mathrm{mg} / \mathrm{kg}$, i.p. $)$, post-treatment $(5 \mathrm{~min})$} & Tonic seizures & $3.21 \pm 0.33[2.57-3.84]$ & $0.86 \pm 0.10[0.67-1.06]$ \\
\hline & Lethality at $1 \mathrm{~h}$ & $2.18 \pm 0.30[1.60-2.76]$ & $0.78 \pm 0.13[0.54-1.03]$ \\
\hline \multirow[t]{2}{*}{ TETS $(0.4 \mathrm{mg} / \mathrm{kg}$, p.o.), post-treatment $(5 \mathrm{~min})$} & Tonic seizures & Maximum protection: $6-8$ & $2.02 \pm 0.26[1.51-2.54]$ \\
\hline & Lethality at $24 \mathrm{~h}$ & & $1.85 \pm 0.27[1.33-2.37]$ \\
\hline
\end{tabular}

In preliminary experiments, we used the MES test to verify the anti-seizure efficacy of perampanel and characterize its time course of action. We found that parenteral perampanel at doses of 1 and $2 \mathrm{mg} / \mathrm{kg}$ conferred peak protection at $10 \mathrm{~min}$ and that protection lasted up to $30 \mathrm{~min}$. In a subsequent dose-response study with a 10 min pre-treatment interval, the $\mathrm{ED}_{50}$ value for seizure protection was $1.50 \mathrm{mg} /$ $\mathrm{kg}$. Our results are consistent with two previous reports. Perampanel in male ddY and male CD1 mice provided protection in the MES seizure test with $\mathrm{ED}_{50}$ values of $1.6 \mathrm{mg} /$ $\mathrm{kg}$, p.o., and $1.7 \mathrm{mg} / \mathrm{kg}$, i.p., respectively (Hanada et al. 2011; Zwart et al. 2014). It has been previously reported that AMPA receptor antagonists induce motor impairment at doses similar to those that are protective in the MES test (Yamaguchi et al. 1993). A similar lack of separation between the doses conferring seizure protection and motor incoordination was observed in the previous studies with perampanel in mice (Hanada et al. 2011; Zwart et al. 2014). Consistent with these prior results, in our study, perampanel also caused motor impairment at doses in the same range as those that conferred seizure protection $\left(\mathrm{ED}_{50}, 1.19 \mathrm{mg} / \mathrm{kg}\right.$, i.p.). Nevertheless, perampanel has acceptable tolerability when used in the treatment of epilepsy indicating that the lack of therapeutic window in rodents does not predict lack of clinical utility. However, perampanel does exhibit a narrow therapeutic window in humans and treatment-emergent side effects, such as dizziness, somnolence, fatigue and gait instability, are common (Rogawski 2017).

In addition to its activity in the MES test, pre-treatment with perampanel protects against seizures in mice induced by the $\mathrm{GABA}_{\mathrm{A}}$ receptor blocker pentylenetetrazol (Hanada et al. 2011). Similarly, we found that pre-treatment with perampanel protected against seizures and lethality induced by TETS, which is also a $\mathrm{GABA}_{\mathrm{A}}$ receptor antagonist (Pressly et al. 2021). The potencies for protection against TETS-induced lethality and the reported activity in the PTZ mouse model (0.94 mg/kg, p.o.; Hanada et al. 2011) were comparable. As an antidote for poisoning, post-treatment is required. We studied post-treatment following a lower dose of TETS $(0.14 \mathrm{mg} / \mathrm{kg})$ that provided a 15 min window during which the treatment drug could be administered and a higher dose $(0.2 \mathrm{mg} / \mathrm{kg})$ that was rapidly lethal requiring the treatment drug to be administered earlier. A 5 min posttreatment interval permitted all animals to receive the treatment drugs with this higher dose. Relatively low doses of either perampanel or diazepam prevented tonic seizures and lethality when administered after the lower dose of TETS. Effective doses of perampanel were substantially lower than those that caused motor impairment. These results indicate that perampanel, and perhaps AMPA receptor antagonists in general, are potentially useful treatments following low-level exposures to TETS. Diazepam was also highly potent at preventing lethality caused by the lower dose of TETS. With a higher dose of TETS that is more rapidly lethal, a larger perampanel dose was required to protect against tonic seizures and lethality. Such higher doses are associated with motor impairment but depending upon the circumstances, a degree of transitory neurological impairment may be acceptable, since the toxicant is lethal. It is noteworthy that perampanel even at very high doses did not cause lethality and animals recovered fully from the neurological impairment. Diazepam was also protective against the higher dose of TETS and as in the case of perampanel, a greater dose was required. However, a relatively smaller increment in diazepam dose was required to protect against the higher TETS dose than was the case for perampanel. Despite the ability of perampanel and diazepam to protect against tonic seizures and lethality, neither of the treatments impacted myoclonic body twitches, and in most situations, even high doses of diazepam only partially suppressed clonic seizures. Therefore, neither of the treatments eliminated all seizure components and can be considered a fully adequate treatment. 
Our results are generally in agreement with a previous study of diazepam in the treatment of seizures induced by a high $(0.4 \mathrm{mg} / \mathrm{kg}$, i.p.) dose of TETS in mice (Shakarjian et al. 2012). In this prior study, pre-treatment or post-treatment with $1 \mathrm{mg} / \mathrm{kg}$ diazepam provided partial protection against tonic seizures and lethality whereas a higher $5 \mathrm{mg} /$ $\mathrm{kg}$ dose was more effective. In rats, Moffett et al. (2019) studied post-treatment with even higher doses of diazepam $(12.5$ and $25 \mathrm{mg} / \mathrm{kg}$ ), which were found to partially protect against lethality produced by a high $(0.6 \mathrm{mg} / \mathrm{kg})$ oral dose of TETS. The benzodiazepines midazolam and lorazepam also enhanced survival. In our study, neither perampanel nor diazepam was fully protective when a high dose of TETS $(0.4 \mathrm{mg} / \mathrm{kg})$ was administered orally, although diazepam performed better than perampanel. Consistent with our observation that diazepam minimally suppresses clonic seizure activity, Shakarjian et al. (2012) found that TETS-induced ictal electroencephalogram (EEG) activity corresponding with clonic motor seizures was not suppressed by diazepam. Despite the similar outcomes, certain experimental differences between our study and that of Shakarjian et al. (2012) are worthy of note. The prior study used C57BL/6 mice and, in preliminary testing, we found these mice to be somewhat less sensitive to TETS than the NIH Swiss mice used here (unpublished). An additional difference is that in the prior study, the treatment was administered after the first clonic seizure whereas we administered the treatment at a fixed time after TETS dosing, which we considered to be a more rigorous test.

Since TETS is a $\mathrm{GABA}_{\mathrm{A}}$ receptor antagonist, it is not unexpected that diazepam, a positive allosteric modulator of $\mathrm{GABA}_{\mathrm{A}}$ receptors, would confer protection against some seizure manifestations. The effective doses of diazepam that we found to protect against TETS-induced tonic seizures and lethality were similar to the doses that protect against seizures induced by other $\mathrm{GABA}_{\mathrm{A}}$ receptor antagonists in mice, including pentylenetetrazol, picrotoxin and bicuculline (Swinyard and Castellion 1966; Shenoy et al. 1982). Our results demonstrate that the AMPA receptor antagonist perampanel is also effective against TETS-induced tonic seizures and lethality. AMPA receptors are the main mediators of fast excitatory synaptic transmission in the central nervous system (Rogawski 2013). Perampanel potently inhibits AMPA receptors, resulting in reduced excitatory neurotransmission in local circuits and also attenuated spread of excitation to adjacent and distant sites. This anti-seizure action is entirely distinct from that produced by drugs that act on $\mathrm{GABA}_{\mathrm{A}}$ receptors. However, AMPA receptor antagonists have broad-spectrum anti-seizure actions, which we have now shown extends to TETS. Despite their distinct mechanisms of action, both perampanel and diazepam are effective in the treatment of tonic seizures and lethality caused by moderate doses of TETS. However, with a high dose
$(0.4 \mathrm{mg} / \mathrm{kg})$, perampanel failed to protect all animals even at very high doses. Perampanel and diazepam could potentially have some utility in the treatment of TETS-induced seizures but neither drug is effective in eliminating all seizure manifestations.

Acknowledgements We thank Dr. Bruce Hammock for providing TETS

Author contributions DZ performed the majority of the experimental work and data analysis, wrote the first manuscript draft, and provided edits to the final manuscript. AD performed some experiments and assisted with the data analysis. MAR secured the funding, conducted data analysis, made the figures, and wrote the manuscript. All authors contributed to the conception.

Funding Research reported in this publication was supported by the CounterACT Program, National Institutes of Health Office of the Director, and the National Institute of Neurological Disorders and Stroke under Award Number U54 NS079202. The content is solely the responsibility of the authors and does not necessarily represent the official views of the National Institutes of Health.

Data availability Data files are available on request.

Code availability Statistical analysis software and documentation are available at: http://mr.ucdavis.edu/laboratory.html.

\section{Declarations}

Conflict of Interest The authors declare that they have no conflict of interest.

Ethics approval All animal experiments were conducted under a protocol approved by the University of California, Davis Institutional Animal Care and Use Committee.

Open Access This article is licensed under a Creative Commons Attribution 4.0 International License, which permits use, sharing, adaptation, distribution and reproduction in any medium or format, as long as you give appropriate credit to the original author(s) and the source, provide a link to the Creative Commons licence, and indicate if changes were made. The images or other third party material in this article are included in the article's Creative Commons licence, unless indicated otherwise in a credit line to the material. If material is not included in the article's Creative Commons licence and your intended use is not permitted by statutory regulation or exceeds the permitted use, you will need to obtain permission directly from the copyright holder. To view a copy of this licence, visit http://creativecommons.org/licenses/by/4.0/.

\section{References}

Bowery NG, Brown DA, Collins JF (1975) Tetramethylenedisulphotetramine: an inhibitor of $\gamma$-aminobutyric acid induced depolarization of the isolated superior cervical ganglion of the rat. $\mathrm{Br} \mathrm{J}$ Pharmacol 53:422-424

Bruun DA, Cao Z, Inceoglu B, Vito ST, Austin AT, Hulsizer S, Hammock BD, Tancredi DJ, Rogawski MA, Pessah IN, Lein PJ (2015) Combined treatment with diazepam and allopregnanolone 
reverses tetramethylenedisulfotetramine (TETS)-induced calcium dysregulation in cultured neurons and protects TETS-intoxicated mice against lethal seizures. Neuropharmacology 95:332-342. https://doi.org/10.1016/j.neuropharm.2015.03.035

Ceolin L, Bortolotto ZA, Bannister N, Collingridge GL, Lodge D, Volianskis A (2012) A novel anti-epileptic agent, perampanel, selectively inhibits AMPA receptor-mediated synaptic transmission in the hippocampus. Neurochem Int 61:517-522

Chen CY, Matt L, Hell JW, Rogawski MA (2014) Perampanel inhibition of AMPA receptor currents in cultured hippocampal neurons. PLoS ONE 9(9):e108021

Dhir A, Bruun DA, Guignet M, Tsai YH, González E, Calsbeek J, Vu J, Saito N, Tancredi DJ, Harvey DJ, Lein PJ, Rogawski MA (2020) Allopregnanolone and perampanel as adjuncts to midazolam for treating diisopropylfluorophosphate-induced status epilepticus in rats. Ann N Y Acad Sci. 1480(1):183-206. https://doi.org/10. 1111/nyas. 14479

Dray A (1975) Tetramethylenedisulphotetramine and amino acid inhibition in the rat brain. Neuropharmacology 14:703-705

Greenfield Jr LJ, Sahaya K, Lee S-H (2021) Benzodiazepines (Chapter 48). In: Wyllie E, editor-in-chief; Gidal BE, Goodkin HP, Jehi L, Loddenkemper T, associate editors. Wyllie's treatment of epilepsy. Principles and practice. 7 th ed. Philadelphia: Wolters Kluwer, p. 575-598

Hanada T, Hashizume Y, Tokuhara N, Takenaka O, Kohmura N, Ogasawara A, Hatakeyama S, Ohgoh M, Ueno M, Nishizawa Y (2011) Perampanel: a novel, orally active, noncompetitive AMPAreceptor antagonist that reduces seizure activity in rodent models of epilepsy. Epilepsia 52:1331-1340

Hanada T, Ido K, Kosasa T (2014) Effect of perampanel, a novel AMPA antagonist, on benzodiazepine-resistant status epilepticus in a lithium-pilocarpine rat model. Pharmacol Res Perspect 2(5): $1-7$

Jett DA, Spriggs SM (2020) Translational research on chemical nerve agents. Neurobiol Dis 133:104335. https://doi.org/10.1016/j.nbd. 2018.11.020

Kokate TG, Svensson BE, Rogawski MA (1994) Anticonvulsant activity of neurosteroids: correlation with $\gamma$-aminobutyric acidevoked chloride current potentiation. J Pharmacol Exp Ther 270(3):1223-1229

Large WA (1975) Effect of tetramethylenedisulphotetramine on the membrane conductance increase produced by $\gamma$-aminobutyric acid at the crab neuromuscular junction. Br J Pharmacol 53:598-599

Lauková M, Velíšková J, Velíšek L, Shakarjian MP (2020) Tetramethylenedisulfotetramine neurotoxicity: what have we learned in the past 70 years? Neurobiol Dis. 133:104491. https://doi.org/10. 1016/j.nbd.2019.104491

Löscher W, Rogawski MA. Epilepsy. (2002) In: Lodge D, Danysz W, Parsons CG, (eds.). Ionotropic glutamate receptors as therapeutic targets. F.P. Graham Publishing Co., Johnson City, pp. 91-132

Moffett MC, Rauscher NA, Rice NC, Myers TM (2019) Survey of drug therapies against acute oral tetramethylenedisulfotetramine poisoning in a rat voluntary consumption model. Neurotoxicology 74:264-271. https://doi.org/10.1016/j.neuro.2019.08.004

Nik AM, Pressly B, Singh V, Antrobus S, Hulsizer S, Rogawski MA, Wulff H, Pessah IN (2017) Rapid throughput analysis of GABA receptor subtype modulators and blockers using $\operatorname{DiSBAC}_{1}(3)$ membrane potential red dye. Mol Pharmacol 92:88-99

Patocka J, Franca TCC, Wu Q, Kuca K (2018) Tetramethylenedisulfotetramine: a health risk compound and a potential chemical warfare agent. Toxics 6(3):51. https://doi.org/10.3390/toxics6030051

Pressly B, Lee RD, Barnych B, Hammock BD, Wulff H (2021) Identification of the functional binding site for the convulsant tetramethylenedisulfotetramine in the pore of the $\alpha 2 \beta 3 \gamma 2 \mathrm{GABA}_{\mathrm{A}}$ receptor.
Mol Pharmacol. 99(1):78-91. https://doi.org/10.1124/molpharm. 120.000090

Rice NC, Rauscher NA, Langston JL, Myers TM (2017) Behavioral intoxication following voluntary oral ingestion of tetramethylenedisulfotetramine: dose-dependent onset, severity, survival, and recovery. Neurotoxicology 63:21-32. https://doi.org/10.1016/j. neuro.2017.08.009

Roberts CJ, James VA, Collins JF, Walker RJ (1981) The action of seven convulsants as antagonists of the GABA response of Limulus neurons. Comp Biochem Physiol C 70:91-96

Rogawski MA (2013) AMPA receptors as a molecular target in epilepsy therapy. Acta Neurol Scand Suppl 197:9-18. https://doi.org/ 10.1111/ane.12099

Rogawski MA (2017) Perampanel. In: Pellock JM, Nordli DR, Sankar R, Wheless JW (eds.). Pediatric Epilepsy, 4th Edition. Demos Medical

Rogawski MA, Hanada T (2013) Preclinical pharmacology of perampanel, a selective non-competitive AMPA receptor antagonist. Acta Neurol Scand Suppl 197:19-24

Shakarjian MP, Velíšková J, Stanton PK, Velíšek L (2012) Differential antagonism of tetramethylenedisulfotetramine-induced seizures by agents acting at NMDA and $\mathrm{GABA}_{\mathrm{A}}$ receptors. Toxicol Appl Pharmacol 265(1):113-121

Shakarjian MP, Ali MS, Velíšková J, Stanton PK, Heck DE, Velíšek L (2015) Combined diazepam and MK- 801 therapy provides synergistic protection from tetramethylenedisulfotetramine-induced tonic-clonic seizures and lethality in mice. Neurotoxicology 48:100-108. https://doi.org/10.1016/j.neuro.2015.03.007

Shenoy AK, Miyahara JT, Swinyard EA, Kupferberg HJ (1982) Comparative anticonvulsant activity and neurotoxicity of clobazam, diazepam, phenobarbital, and valproate in mice and rats. Epilepsia 23(4):399-408

Steinhoff BJ (2014) Efficacy of perampanel: a review of pooled data. Epilepsia 55(Suppl 1):9-12. https://doi.org/10.1111/epi.12493

Swinyard EA, Castellion AW (1966) Anticonvulsant properties of some benzodiazepines. J Pharmacol Exp Ther 151(3):369-375

Twele F, Bankstahl M, Klein S, Römermann K, Löscher W (2015) The AMPA receptor antagonist NBQX exerts anti-seizure but not antiepileptogenic effects in the intrahippocampal kainate mouse model of mesial temporal lobe epilepsy. Neuropharmacology 95:234-242. https://doi.org/10.1016/j.neuropharm.2015.03.014

Vito ST, Austin AT, Banks CN, Inceoglu B, Bruun DA, Zolkowska D, Tancredi DJ, Rogawski MA, Hammock BD, Lein PJ (2014) Post-exposure administration of diazepam combined with soluble epoxide hydrolase inhibition stops seizures and modulates neuroinflammation in a murine model of acute TETS intoxication. Toxicol Appl Pharmacol. 281(2):185-194. https://doi.org/10. 1016/j.taap.2014.10.001

Yamaguchi S, Donevan SD, Rogawski MA (1993) Anticonvulsant activity of AMPA/kainate antagonists: comparison of GYKI 52466 and NBOX in maximal electroshock and chemoconvulsant seizure models. Epilepsy Res 15(3):179-184

Zolkowska D, Banks CN, Dhir A, Inceoglu B, Sanborn JR, McCoy MR, Bruun DA, Hammock BD, Lein PJ, Rogawski MA (2012) Characterization of seizures induced by acute and repeated exposure to tetramethylenedisulfotetramine. J Pharmacol Exp Ther 341(2):435-446. https://doi.org/10.1124/jpet.111.190579

Zwart R, Sher E, Ping X, Jin X, Sims JR Jr, Chappell AS, Gleason SD, Hahn PJ, Gardinier K, Gernert DL, Hobbs J, Smith JL, Valli SN, Witkin JM (2014) Perampanel, an antagonist of $\alpha$-amino-3hydroxy-5-methyl-4-isoxazolepropionic acid receptors, for the treatment of epilepsy: studies in human epileptic brain and nonepileptic brain and in rodent models. J Pharmacol Exp Ther 351(1):124-133

Publisher's Note Springer Nature remains neutral with regard to jurisdictional claims in published maps and institutional affiliations. 